\title{
Effects of dietary vegetable oil supplementation on fillet quality traits, chemical and fatty acid composition of African catfish (Clarias gariepinus)
}

\author{
ANDRÁS SZABÓ' ${ }^{1}$, RÓBERT ROMVÁRI ${ }^{1}$, LÁSZLÓ SZATHMÁRI ${ }^{2}$, TAMÁS MOLNÁR' ${ }^{1}$, LÁSZLÓ \\ LOCSMÁNDI ${ }^{1}$, GYÖRGY BÁZÁR' ${ }^{1}$, ESZTER MOLNÁR ${ }^{2}$, PÉTER HORN ${ }^{1}$ and CSABA HANCZ1
}

${ }^{1}$ Faculty of Animal Science, University of Kaposvár, Kaposvár, Hungary, ${ }^{2}$ Faculty of Agriculture and Food Science, University of Western Hungary, Mosonmagyaróvár, Hungary

\section{Abstract}

The effects of dietary fish oil (FO), soybean oil (SO) and linseed oil (LO) (12\% crude fat content each) in African catfish (Clarias gariepinus) diets were tested on the fillet flesh quality, chemical and fatty acid (FA) composition, after 3 and 6 weeks of feeding. The bodyweight gain of fish and the fillet dry matter, crude protein and crude fat content was not different among the divergent treatments. High ( $>20 \%)$ total n3 FA supplementation significantly increased the moisture loss of fillet (FO, LO). Applying the simple FA dilution model (JOBLING 2004a, 2004b), the incorporation dynamics of the most largely dosed FAs were accurately predictable after 3 weeks ( $R^{2}$ between observed and estimated data for total n3 FAs: FO 0.95, LO 0.73 and for a-linolenic acid, LO 0.97). In the fillet FA composition the metabolism of $\mathrm{n} 3$ acids was more pronounced. The large provision of a-linolenic acid (LO) had a pronounced effect on the longchain, polyunsaturated n3 FA proportions (eicosapentaenoic and docosapentaenoic acids), while no effect was experienced on docosahexaenoic acid. This study suggests that daily bodyweight gain is not, while fillet flesh quality and FA composition is slightly compromised when fish oil is substituted for vegetable oils.

Keywords: African catfish, fatty acid incorporation, fillet, flesh quality, vegetable oils

\section{Zusammenfassung}

\section{Der Einfluss von Pflanzenfetten auf die Fleischqualität, chemische Zusammensetzung und das Fettsäuremuster beim Afrikanischen Wels (Clarias gariepinus)}

Untersucht wurde der Einfluss einer Zugabe von Fischöl (FO), Sojaöl (SO) und Leinöl (LO) mit einem Rohfettgehalt von jeweils $12 \%$ auf die Fleischqualität, chemische Zusammensetzung und das Fettsäuremuster beim Afrikanischen Wels über eine Zeitdauer von 3 bis 6 Wochen. Verglichen mit der Kontrollvariante ergaben sich bei den drei Versuchsvarianten keine Einflüsse auf den Körperzuwachs, den Rohfett-, Eiweiß- sowie Trockensubstanzanteil. Das höhere $n 3$ Fettsäureangebot ( $>20 \%$ ) gegenüber der Kontrolle verminderte bei den FO und LO Varianten in hohem Maße das Wasserbindungsvermögen des Fleisches. Durch die Anwendung des Modells für Fettsäureverdünnung nach JOBLING (2004a, 2004b) war die Inkorporationsdynamik der wichtigsten Fettsäuren drei Wochen nach Zugabe der 
unterschiedlichen Futterfette mit hoher Genauigkeit schätzbar. Die $\mathrm{R}^{2}$ Werte zwischen gemessenen und geschätzten Werten betrugen bei FO 0,95; LO 0,73 und für die a-Linolensäure 0,97. Der n3 Fettsäuremetabolismus war im Fischfleich stärker ausgeprägt. Die hohe Versorgung mit a-Linolensäure übte einen großen Einfluss auf die n3 Fettsäuren besonders auf die Eicosapentaensäure sowie den Docosapentaensäuregehalt aus, während der Docosahexaensäureanteil nicht verändert wurde. Die Ergebnisse zeigen, dass die Zugabe von Pflanzenöl den Körperzuwachs nicht beeinflusste jedoch einen negativen Effekt auf die Fleischqualität und die Fettsäurezusammensetzung des Fischfleisches bewirkte.

Schlüsselwörter: Afrikanischer Wels, Fettsäureinkorporation, Filet, Fleischqualität, Pflanzenfett

\section{Introduction}

Highly unsaturated, essential $\mathrm{n} 3$ fatty acids have beneficial health effects and are more and more frequently ingested via fish or fish products (BURR 1981). Just like other vertebrate species, fish also need essential fatty acids (FAs), albeit their qualitative and quantitative requirements strongly differ from those of humans (GREENE and SELIVONCHICK 1987). Freshwater fish, including also carnivorous species, as compared to seawater fish, are superior in converting both $n 3$ and $n 6$ precursor FAs to highly unsaturated, longchain fatty acids, due to their origin in environs basically lacking these FAs (AGABA et al. 2005). Accordingly, studies on the dietary fatty acid incorporation and their consequent metabolism in both marine and freshwater fish are intensely performed. In marine fish, fatty acid incorporation experiments are highly successful for the accurate prediction of the fillet fatty acid composition (JOBLING 2004a, 2004b), as well in the pre-defined modification of the fillet FA profile, e.g. for the production of cardioprotective human diets (TORSTENSEN et al. 2004).

Besides a very robust knowledge on the fatty acid metabolism of sea- and freshwater species (GREENE and SELIVONCHICK 1987, HENDERSON and TOCHER 1987), the contribution of dietary fatty acids to the fillet quality attributes is less known. A basic mode of action of dietary highly unsaturated FAs may be connected to the fact that they are effectively incorporated into the cellular membranes (HENDERSON and TOCHER 1987). Thus, an altered cellular lipid profile may ultimately lead to severe modifications of the fillet quality attributes, as it has been demonstrated for the thawing loss process of catfish fillets (BAKER 1997). The link between dietary fatty acids and fillet water-holding capacity may be the cellular membrane rigidity, as influenced by the diet (DOBRETSOV et al. 1977).

The experimental results of WING-KEONG et al. (2003) supported evidence that vegetable oil, e.g. palm oil may be a successful alternative for the frequently used fish oil in African catfish feeds. As far as the authors are aware, the effects of relatively easily accessible vegetable oils on the conventional fillet flesh quality indices have been less investigated. Therefore, the aim of the present approach was to test the performance of two vegetable oils in shaping the fillet fatty acid profile and quality, as compared to the classical fish oil. 


\section{Material and methods}

\section{Experimental fish, feeding and culture facilities}

African catfish stock was obtained from the Tuka fish farm (Szarvas Fish Ltd., Szarvas, Hungary), where rearing was carried out in an intensive system using mixed geothermic water supply. At the average size of $1 \mathrm{~kg}$, juveniles were transported to the Fish Laboratory of the Kaposvár University. At the beginning of the experiment, the initial body weight

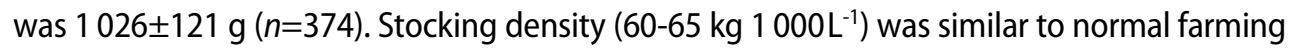
conditions. The experimental unit had a total useful volume of $10000 \mathrm{~L}$ attached to a simple bio-filter unit and a $1600 \mathrm{~L}$ settling tank from where the water was pumped back to the fish keeping units. The daily water replacement rate was about $10 \%$ of the useful volume. The water flow rate was adjusted to $2.5 \mathrm{~L} / \mathrm{min}$ and the temperature was $28 \pm 0.5^{\circ} \mathrm{C}$. Water temperature was measured daily over the 42 -day rearing interval with laboratory thermometer $\left( \pm 0.1^{\circ} \mathrm{C}\right)$. Experimental fish were weighed the initial point and after 3 and 6 weeks in the study. Each time 5-5 fish from each dietary treatment (one fish from one tank) were killed after anaesthesia (Norcaicum, para-amino-benzoic-acidethylester, Egis, Budapest, Hungary), according to MATUK (1987). After dissection, fillet samples were analyzed for chemical composition according to standard AOAC (1990) methods. The crude fat and crude protein (total $\mathrm{N} \times 6.25$ ) contents were interpreted on a dry matter basis. The analysis of the diets was identical with that of fillet samples.

The diet before and in the study was characterized by the chemical and fatty acid composition given in Table 1. The experimental feeds contained, besides the basic $6 \%$ crude fat content $6 \%$ added oil from different sources: fish oil, and two vegetable oils, soybean and linseed oil.

The feeding lasted for 42 days, which was preceded by a 14-day conditioning period. During conditioning, fish were kept in the same system as during the trial. In this period fish were fed a commercial catfish diet (basal diet) containing $60 \mathrm{~g} \mathrm{~kg}^{-1}$ of crude fat. Diets were fed six times daily, from 8 to $18 \mathrm{~h}$, according to appetite. Each diet was fed in 5 aerated tanks working as a part of a recirculation system. The bodyweight gain of fish showed no significant differences, while the feed conversion ratio of fish fed on FO (1.625) was significantly higher $(P<0.05)$ than that of the SO (1.235) and LO (1.330) groups.

Experimental tanks were covered with black plastic, which was removed only for the short periods of feeding and cleaning. Dark environment and frequent feeding helped to avoid stress and aggression among fish.

\section{Fillet flesh quality investigation}

Fillet $\mathrm{pH}$ was measured at $45 \mathrm{~min}$ and $24 \mathrm{~h}$ post mortem, by a Testo 205 precision $\mathrm{pH}$ meter (Testo AG, Lenzkirch, Germany). The colour (CIE Lab, $L^{*}$ - lightness, $a^{*}$ - redness, $b^{*}$ - yellowness) of the fresh fillet was determined by a Minolta ChromaMeter 300 apparatus (Minolta, Osaka, Japan). Dripping loss was determined by the method of HONIKEL (1998). To determine the so-called cooking loss, fillet samples (100 g) were closed into sealed bags and were cooked at $75^{\circ} \mathrm{C}$ for $20 \mathrm{~min}$. The exudate weight, as expressed in the percentage of the initial sample weight was referred to as cooking loss. The thawing loss was determined by the same manner, i.e. samples $(25 \mathrm{~g})$ were frozen $\left(-20^{\circ} \mathrm{C}\right)$ and 
thawed to room temperature after 2 days. Moreover, fillet dry matter content was determined by drying to constant weight at $103^{\circ} \mathrm{C}$, and the Warner-Bratzler shear force of $15 \times 15 \mathrm{~mm}$ fillet quadratic cuts was determined from the cooked samples, on a ZwickRoell Z105 precision equipment (Zwick GmbH \& Co. KG, Ulm, Germany). The peak shearing force value was recorded from 3 cuts and the mean values were given.

Table 1

Chemical and fatty acid composition of the diets in the study

Chemische und Fettsäurezusammensetzung der Fütterungsvarianten

\begin{tabular}{|c|c|c|c|c|}
\hline & Basal diet & Soybean oil & Linseed oil & Fish oil \\
\hline \multicolumn{5}{|l|}{ Chemical composition } \\
\hline Dry matter (DM), \% & 86.5 & 86.1 & 87.2 & 87.8 \\
\hline Crude ash, \% DM & 7.7 & 7.77 & 7.55 & 7.66 \\
\hline Crude protein, \% DM & 53.4 & 47.9 & 48.3 & 47.4 \\
\hline Crude fat, \% DM & 6.0 & 12.1 & 12.1 & 12.0 \\
\hline Crude fiber, \% DM & 2.30 & 2.10 & 2.22 & 2.27 \\
\hline \multicolumn{5}{|l|}{ Fatty acid composition } \\
\hline $\mathrm{C} 12: 0$ & 0.11 & 0.05 & 0.05 & 0.07 \\
\hline $\mathrm{C} 14: 0$ & 0.86 & 1.71 & 1.62 & 4.35 \\
\hline $\mathrm{C} 14: 1 \mathrm{n} 5$ & 0.13 & 0.06 & 0.05 & 0.12 \\
\hline C15:0 & 0.18 & 0.21 & 0.20 & 0.49 \\
\hline $\mathrm{C} 16: 0$ & 21.19 & 14.63 & 12.92 & 15.63 \\
\hline C16:1 n7 & 4.79 & 2.06 & 2.00 & 3.97 \\
\hline C17:0 & 0.37 & 0.27 & 0.25 & 0.53 \\
\hline C17:1 n7 & 0.19 & 0.35 & 0.27 & 0.67 \\
\hline C18:0 & 5.75 & 4.11 & 3.54 & 2.72 \\
\hline C18:1 n9 & 27.34 & 20.63 & 18.26 & 15.78 \\
\hline C18:1 n11 & & 1.98 & 1.82 & 2.26 \\
\hline $\mathrm{C} 18: 2 \mathrm{n} 6 \mathrm{t}$ & & 0.12 & 0.05 & 0.41 \\
\hline C18:2 n6 c & 33.16 & 34.45 & 25.42 & 15.94 \\
\hline C18:3 n6 & 0.06 & 0.04 & 0.04 & 0.08 \\
\hline C18:3 n3 & 1.73 & 4.46 & 19.14 & 2.66 \\
\hline C20:0 & 0.12 & 0.31 & 0.21 & 0.23 \\
\hline C20:1 n9 & 0.63 & 2.12 & 1.97 & 6.94 \\
\hline C20:2 n6 & 0.2 & 0.27 & 0.27 & 0.34 \\
\hline C20:3 n3 & 0.07 & 0.05 & 0.05 & 0.07 \\
\hline C20:3 n6 & 0.01 & 0.10 & 0.12 & 0.15 \\
\hline C20:4 n6 & 0.43 & 0.29 & 0.28 & 0.42 \\
\hline C20:5 n3 & 0.7 & 2.53 & 2.50 & 5.52 \\
\hline C22:1 n9 & 0.02 & 2.36 & 2.14 & 8.19 \\
\hline C22:5 n3 & 0.16 & 0.63 & 0.66 & 1.01 \\
\hline C22:6 n3 & 1.66 & 6.02 & 5.95 & 11.06 \\
\hline C24:0 & & 0.04 & 0.03 & 0.05 \\
\hline $\mathrm{C} 24: 1 \mathrm{n} 9$ & 0.1 & 0.16 & 0.17 & 0.31 \\
\hline$\sum \mathrm{n} 3$ & 4.32 & 13.69 & 28.30 & 20.33 \\
\hline$\Sigma \mathrm{n} 6$ & 33.86 & 35.28 & 26.18 & 17.36 \\
\hline$\Sigma \mathrm{n} 6 / \Sigma \mathrm{n} 3$ & 7.84 & 2.58 & 0.93 & 0.85 \\
\hline$\Sigma$ monoenoic & 33.20 & 29.72 & 26.69 & 38.24 \\
\hline$\Sigma$ PUFA & 38.18 & 48.96 & 54.48 & 37.69 \\
\hline Unsaturation index ${ }^{1}$ & 121.5 & 166.4 & 188.8 & 181.3 \\
\hline Average fatty acyl chain length ${ }^{2}$ & 17.54 & 18.07 & 18.09 & 18.50 \\
\hline
\end{tabular}

${ }^{1} 1(\Sigma$ monoenoic FA $)+2(\Sigma$ dienoic FA $)+3(\Sigma$ trienoic FA $), \quad{ }^{2} \Sigma(\%$ each FA $\times$ number of carbons in the chain $) /(\%$ total FAs $)$ 


\section{Fatty acid composition}

The fatty acid composition was determined from the complex fat content of $5 \mathrm{~g}$ samples. After the extraction (FOLCH et al. 1957), fatty acids were converted to methyl esters by means of $\mathrm{BF}_{3}$ and methanol. Fatty acid methyl esters were analysed on an Agilent Technologies (Santa Clara, CA, USA) $6890 \mathrm{~N}$ type capillary gas-liquid chromatograph system, with a SP-23804 capillary column $(30 \mathrm{~m} \times 0.25 \mathrm{~mm}$ inside diameter, $0.20 \mu \mathrm{m}$ film, Supelco, Bellefonte, PA, USA) and a flame ionization detector. Characteristic operating conditions were: injector temperature: $270^{\circ} \mathrm{C}$, detector temperature: $300^{\circ} \mathrm{C}$, helium flow: $28 \mathrm{~cm} \mathrm{~s}^{-1}$. The oven temperature was programmed from 80 to $205^{\circ} \mathrm{C}$ and increased by $2.5^{\circ} \mathrm{C} \mathrm{min}-1,5 \mathrm{~min}$ at $205^{\circ} \mathrm{C}$, increased from 205 to $250^{\circ} \mathrm{C}$ at $10^{\circ} \mathrm{C} \mathrm{min}^{-1}$, and $5 \mathrm{~min}$ at $250^{\circ} \mathrm{C}$. Individual fatty acids were identified based on their retention times, as assessed from a standard fatty acid mixture (Mixture Me 105, Larodan Fine Chemicals, Malmö, Sweden). The so-called unsaturation index (UI) was defined as the number of double bonds in 100 fatty acyl chains.

\section{Statistical analysis}

Fatty acid and fillet quality (flesh quality and chemical composition) data between groups were compared by multivariate analysis of variance, with the Tukey post hoc test. Bodyweight was handled as covariant, while treatment duration and fat source were set as fixed factors in the model.

The FA incorporation was tested on the basis of the so-called dilution hypothesis (JOBLING 2004a, 2004b). The basis of the hypothesis is that the increasing addition of a fatty acid into the diet induces a change in the tissue fatty acid proportion that can be predicted as follows:

$$
P_{T}=P_{R}+\frac{P_{I}-P_{R}}{\frac{Q_{T}}{Q_{1}}}
$$

where $P_{T}$ is the percentage of the given fatty acid in the fish tissue at the time point $T, P_{l}$ is the initial fatty acid percentage in the tissue, while $P_{R}$ is the percentage of the fatty acid in the tissues of the reference group, i.e. in a group with a rather long fatty acid supplementation period. $Q_{I}$ and $Q_{T}$ represent the information on the fish growth, i.e. this measure is applied to express the body or fillet weight gain. Based on the hypothetic assumption that fillet fat content shows only minor changes within the rearing, the fillet weight was the trait used to characterize the growth in our study. The model includes the assumption that fish grow continuously throughout their lifespan (ASHTON et al. 2005). The so-called reference groups were those receiving 6 weeks of experimental oil supplementation, and the estimation was performed for those receiving the oil supplementations for 3 weeks.

In all instances SPSS 10 for Windows (1999) was used for the statistical analysis. 


\section{Results}

Effects of different dietary fatty acid supplementation

on the fillet flesh quality and bodyweight gain

Statistically proven effect of the dietary fat source was experienced only on two fillet flesh quality traits ( $\mathrm{pH} 45$ and $\mathrm{b}^{*}$ ), while the duration of dietary fatty acid supplementation had marked effect on most of the traits. The effects and the between-sampling differences are indicated in Table 2. Clearly defined effect of the treatment duration was found on $\mathrm{pH} 45, \mathrm{pH} 24$, a*, dripping loss and thawing loss. As seen in Table 2, bodyweight had a significant influence on the fillet $\mathrm{pH} 24$ value, dry matter content and shearresistance. The values of average daily gain $\left(\mathrm{g} \mathrm{day}^{-1}\right.$ ) were as follows: 12.7 (FO), 12.4 (LO) and 13.3 (SO), without statistically significant differences.

\section{Influence of different fatty acid supplementation on the fillet chemical composition}

Interestingly, neither fillet dry matter content, nor the crude fat and the crude protein content showed statistically significant alterations during the entire experiment.

\section{Effects of different fatty acid supplementation} on the fillet fatty acid profile

As expected, both the dietary fat source and the duration of the feeding had marked effects on fillet fatty acids. Detailed fillet FA compositional data are summarized in Table 3, handling the three dietary treatments (FO, LO, SO) in a separated manner.

The proportion of total $\mathrm{n} 3$ fatty acids increased in the FO and SO groups, while in the LO group no statistically proven increment was shown. The proportion of a-linolenic acid $(\mathrm{C} 18: 3 \mathrm{n} 3, \mathrm{ALA})$ increased in all groups, though the SO group reached lower proportions, as compared to the FO, in spite of the ca. two-fold higher ALA supplementation of the latter diet. The fillet proportion of eicosapentaenoic acid (C20:5 n3, EPA) increased according to the dietary supplementation. Interestingly, while the $\mathrm{SO}$ and LO diets contained similar EPA amounts, the final fillet proportion of EPA was slightly higher in the LO samples. The docosapentaenoic (C22:5 n3, DPA) and docosahexaenoic acid (C22:6 n3, DHA) proportions in the fillet increased according to the graded dietary uptake of these acids.

The total $\mathrm{n} 6$ fatty acids showed either no change (SO, LO), or decreased, in parallel with the decreased dietary uptake (FO). The proportion of linoleic acid (C18:2 n6, LA) decreased only in the fillet samples of the FO group, according to the drastically decreased LA proportion of the diet. In contrast, arachidonic acid (C20:4 n6, AA) did not show marked proportional reduction in either of the treatments, albeit the SO and LO diets contained lower amounts of this acid, as compared to the basal diet.

The markedly altered dietary $n 3$ and $n 6$ doses were effective in the reduction of the n6/n3 fatty acid ratio in the FO and LO groups. The unsaturation index (UI) increased in the former two groups, while the average fatty acyl chain length increased in all three groups to the end of the 6 th week. 


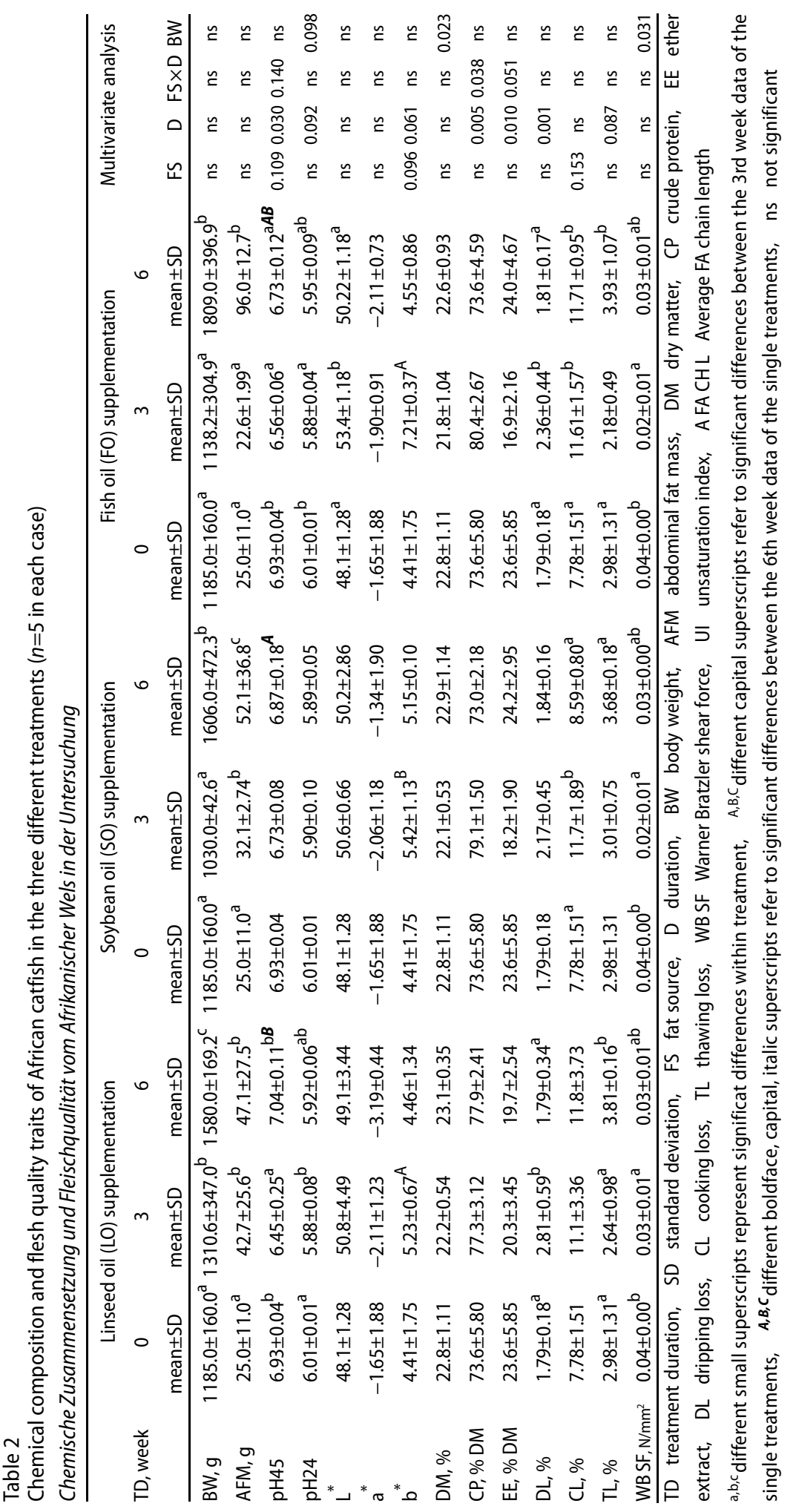




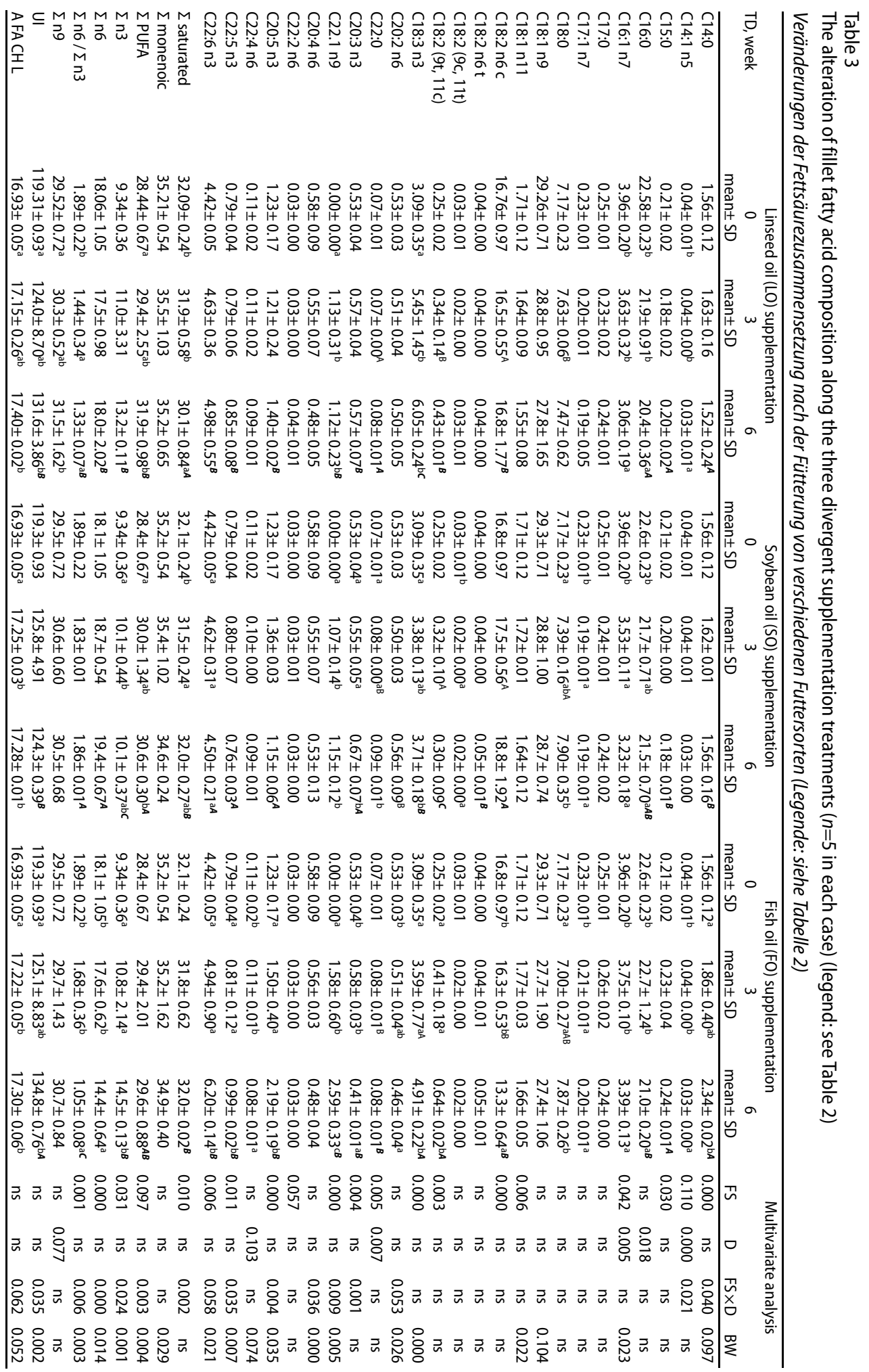




\section{Testing of the fatty acid dilution model}

The dietary fatty acid incorporation process was tested with the application of the dilution model of JOBLING (2004a), worked out for carnivorous fish. The estimation was performed for the dataset obtained after 3 weeks onset of the fatty acid supplementation. Table 4 contains the determination coefficients obtained from the correlation analysis between the observed and estimated fatty acid results, for the 3 types of dietary oil supplementation. Only the major or mostly interesting fatty acids were evaluated with the application of the model, only for the cases where the dietary fatty acid component dose increased, as compared to the basal diet.

As it is visible in Table 4, the estimation was the most robust in the cases where the dietary supplementation meant an expressed elevation of the given fatty acid, i.e. ALA in the LO group, EPA in the FO group, and total $n 3$ fatty acids in the FO and LO groups.

Table 4

Determination coefficients $\left(R^{2}\right)$ between observed and estimated (by means of the dilution model) fatty acid data at the 3 rd week of trial ( $n=5$ in each case)

Zusammenhang zwischen gemessenen und geschätzten Werten $\left(R^{2}\right)$ nach dem Modell JOBLING (2004a, 2004b) nach der dritten Versuchswoche

\begin{tabular}{lccc}
\hline Fatty acid & Fish oil & Soybean oil & Linseed oil \\
\hline C18:3 n3 & ns & 0.42 & 0.97 \\
C20:5 n3 & 0.83 & $n s$ & 0.85 \\
C22:5 n3 & ns & $n s$ & $n s$ \\
C22:6 n3 & ns & $n s$ & $n s$ \\
Total n3 & 0.95 & 0.56 & 0.73 \\
\hline
\end{tabular}

\section{Discussion}

Effects of different fatty acid supplementation

on the body weight gain and fillet flesh quality

The results of the present approach aiming the partial substitution of fish oil for vegetable oils demonstrate that the weight gain of fish was not influenced negatively by the vegetable oils. In the study of WING-KEONG et al. (2003) on African catfish, palm oil and sunflower oil resulted in higher growth performances, as compared to high n3 PUFA diets, containing cod liver oil. A number of studies reported similar results, when relatively saturated fatty acid compositional diets led to better growth characteristics of African catfish (HOFFMAN et al. 1995, LEGENDRE et al. 1995). In contrast, Channel catfish (Ictalurus punctuatus) was reported to utilize fish oil better for growth, as compared to vegetable oils (MANNING et al. 2006).

The compositional alteration of the fillet, as induced by the divergent dietary fat types was statistically proven by the $\mathrm{pH}$ and in the yellow color component $\left(\mathrm{b}^{*}\right)$, although the between-sampling differences within the divergent treatments (i.e. SO, LO and FO) were negligible. Moreover, FLIS et al. (2007) also reported the alteration of the muscle $b^{*}$ component as a result of dietary manipulation. The fact that the effect of treatment 
duration, as compared to that of fat source, was more expressed on the fillet quality traits suggests that 3 weeks on a finishing diet may not always lead to the demanded quality alterations of the fillet. This assumption is supported by the recommendations of TORSTENSEN et al. (2004), applying a 25 -week period for the fillet fatty acid profile modification of Atlantic salmon, and also by that of BAKER (1997), reporting an 56-day treatment period for African catfish.

Possibly the mainly interesting finding on the fillet quality is the marked influence of fat source and treatment duration on the water holding capacity of fillet, as expressed by different exudative moisture losses. Though significance was not proven for the effects of fat source (only for cooking loss, $P=0.153$ ), the treatment duration affected the dripping loss and also the thawing loss. The tissue moisture retention ability of African catfish has been shown to be influenced by the oxidation level and PUFA proportion of the dietary fat (BAKER 1997), and by rainbow trout as well by age (WERNER et al. 2008). Interestingly, the dripping loss was higher in LO and FO groups at the 3rd week, as compared to the data obtained at the end of the trial (6th week). In the authors opinion, this may be a result of a longer-term adaptation, namely the one-step change to the LO and FO diets may have led to a progressive in vivo lipid peroxidation, which was later compensated by an adaptation of the antioxidant enzymes. A highly similar phenomenon was experienced by SZABÓ et al. (2004) in rabbit skeletal muscles, and Nile Tilapia (2007, unpublished observation), when a diet with saturated fatty acids was changed to a highly unsaturated one. Unfortunately, in the present study in vivo lipid peroxidation was not determined, albeit in rabbits it has been characterized by the malondialdehyde concentration of the muscle.

Concerning the shearing force of the fillet, the present results are supported by those of REGOST et al. (2003), reporting that total substitution of fish oil either for linseed oil or soybean oil does not measurably influence the shearing resistance of fillet, in turbot (Psetta maxima).

\section{Effects of different fatty acid supplementation on the fillet fatty acid profile and metabolism}

Analyzing the dietary fatty acid incorporation into fillet complex lipids, there is no defined mathematical model besides the simple dilution models of ROBIN et al. (2003) and JOBLING $(2004 \mathrm{a}, 2004 \mathrm{~b})$ for the interpretation of the process. Analyzing the precursorproduct fatty acid relationships needs to fulfil the condition that the final fillet fatty acid profile is, at least partly, shaped by the endogenous fatty acid synthetic processes, i.e. elongation and desaturation (RUYTER et al. 2003). This is, however, rather true in freshwater fish, especially under intensive rearing conditions and growth (JOBLING 2004b).

The results found for ALA are interesting considering the fact that a ca. two-fold higher ALA supplementation (SO), as compared to the FO diet, induced lower tissue ALA proportions. Naturally, the ca. one magnitude higher ALA supplementation led to markedly higher tissue proportions in the LO treatment. The background of the fate of ALA may be the well-known phenomenon that ALA desaturation and elongation of fish is augmented when instead of fish oil vegetable oils are fed, as reported by BELL et al. (2001) in Atlantic salmon. 
The effect of the high dietary provision of the precursor fatty acid (ALA) was also reflected in the tissue proportion of EPA. In the formation of the tissue EPA levels a very expressed dietary effect and the role of endogenous synthesis was supposed. The former assumption is based on the finding that double amounts of dietary EPA (FO vs. SO) led to a nearly double tissue proportion of this fatty acid in the FO fillets. In contrast, identical dietary EPA supplementation in the LO and SO groups led ultimately to higher tissue EPA levels in the LO group, suggesting the role of endogenous fatty acid transformation, based on ALA as precursor.

In the tissue proportion of DPA some slight effects of the dietary precursor (i.e. ALA) load might be supposed, since by totally identical dietary DPA, and as well EPA levels (SO and LO), the fillet in the LO treatment tended to contain higher DPA proportions, however without statistical significance. A similar tendency was supposed for DHA, where all the dietary fatty acids antecedent in the $\mathrm{n} 3$ biosynthetic pathway were dosed in identical proportions in the $\mathrm{SO}$ and $\mathrm{LO}$ diets, except ALA, while a significantly higher DHA level was found in the fillet fatty acid profile of the LO fish.

The present results concerning the final products of the $n 3$ FA biosynthesis suggest that the substitution of fish oil with vegetable oils does not lead to identically beneficial fatty acid profile of the catfish fillet. In our study, however, the dietary ensured proportions of EPA, DPA and DHA were higher in the FO diet, resulting ultimately in slightly higher proportions of these acids, most probably resulting from direct incorporation.

It was hypothesized that that the relative dietary overload of a precursor does not unconditionally lead to an increased tissue proportion of the product fatty acid. Similar findings were reported by BELL et al. (2006), in Atlantic cod fillet, where the feeding of stearidonic acid (C18:4 n3), another $n 3$ precursor, led to reduced levels EPA and DHA, as compared to FO. From our study it seems that high dietary $\mathrm{n} 3$ supplementation, as compared to the natural diets, primarily activated the steps of the $n 3$ biosynthesis pathway, to the detriment of the $n 6$ FAs. This latter finding was proven by the practically minimal change of the n6 FAs in the tissue, and was supported by RUYTER et al. (2000), reporting that the rate of conversion between LA and AA is thus influenced by the dietary balance of $n 3$ fatty acids. Since both biosynthetic processes (i.e. $n 3$ and $n 6$ desaturation) are mediated by $\Delta 6$ desaturase, the large dietary ALA amount may out compete LA for the enzyme (MILLER et al. 2007). Moreover, according to STUBHAUG et al. (2005), the affinity of elongating and desaturating enzymes is higher towards the $n 3$ fatty acid family, as compared to the $n 6$ or $n 9$ ones.

\section{Dilution model of fatty acid incorporation}

According to JOBLING (2004a, 2004b), the supplementation of finishing diets with the desired fatty acids in increased quantities may lead to precisely predictable fillet fatty acid profiles. By testing this hypothesis, we only used a relatively short feeding period, but intensive keeping conditions. In our experience, only the incorporation of the fatty acids in drastically increased dietary amounts occurs highly efficiently, as proven by the results of Table 4. The rather high accuracy of the predictions supports the hypothesis that the alteration in the fillet fatty acid profile, as induced by the dietary treatment is a 
dilution (JOBLING 2004a, ROBIN et al. 2003). However, the endogenous fatty acid synthesis has also to be considered as a determination factor of the overall fillet fatty acid profile. Since the fat content of fillet contains rather high proportions of storage triglycerides, and fish are growing, the endogenous modification of dietary fatty acids is of secondary importance. In contrast, dietary fatty acids are more directly incorporated, with only minor elongation or desaturation (JOBLING 2004a).

\section{Conclusions}

The different vegetable oil supplementation, as compared to the fish oil, did not negatively affect the daily bodyweight gain, while high dietary $n 3$ fatty acid levels were shown to augment fillet moisture loss. Analyzing the $\mathrm{n} 3$ fatty acid synthetic pathway it was found that an uncommonly high dietary $\mathrm{n} 3$ precursor level may not unconditionally implicate high $\mathrm{n} 3$ longchain PUFA levels in fillet of African catfish. Feeding vegetable oils, the correlative changes of fillet FA profile were well predictable for the major dietary FAs by a simple dilution model.

\section{Acknowledgements}

The financial support of the Economy-Oriented Agricultural Research Project (NKTH 13516-GAK-904/2005), and that of the Bolyai János Research Grant (to A.Sz.; BO/00108/07; to T.M.; BO/00462/08/4) by the Hungarian Academy of Science is gratefully acknowledged.

\section{References}

Agaba MK, Tocher DR, Zheng X, Dickson CA, Dick JR, Teale AJ (2005) Cloning and functional characterisation of polyunsaturated fatty acid elongases of marine and freshwater teleost fish Comp Biochem Physiol B 142, 342-52

AOAC (1990) Official methods of analysis of Association of Official Analytical Chemists, 15th ed, AOAC Arlington VA USA

Ashton C, Bayol S, Mcentee G, Maltby V, Stickland N (2005) Prenatal influences on skeletal muscle development in mammals birds and fish. Arch Tierz 48 SI, 4-10

Baker RTM (1997) The effects of dietary a-tocopherol and oxidised lipid on post-thaw drip from catfish muscle. Anim Feed Sci Technol 65, 35-43

Bell JG, McEvoy J, Tocher DR, McGhee F, Campbell PJ, Sargent JR (2001) Replacement of fish oil with rapeseed oil in diets of Atlantic salmon (Salmo salar) affects tissue lipid compositions and hepatocyte fatty acid metabolism. J Nutr 131, 1535-43

Bell JG, Strachan F, Good JE, Tocher DR (2006) Effect of dietary echium oil on growth fatty acid composition and metabolism gill prostaglandin production and macrophage activity in Atlantic cod (Gadus morhua L). Aquacult Res 37, 606-17

Burr GO (1981) The essential fatty acids fifty years ago. Prog Lipid Res 20, 27-9

Dobretsov GE, Borshevskaya TA, Petrov VA, Vladimirov YA (1977) The increase of phospholipid bilayer rigidity after lipid peroxidation. FEBS Lett 84, 125-8

Flis M, Sobotka W, Antoszkiewicz Z, Lipiński K, Zduńczyk Z (2007) Effect of husked and naked oat used in the diets supplemented with linseed oil on the growth performance of pigs carcass and meat quality. Arch Tierz 50, 161-71

Folch JM, Lees M, Sloane-Stanley GH (1957) A simple method for the isolation and purification of total lipids from animal tissues. J Biol Chem 226, 495-509

Greene DH, Selivonchick DP (1987) Lipid metabolism in fish. Prog Lipid Res 26 (1987) 53-85

Henderson RJ, Tocher DR (1987) The lipid composition and biochemistry of freshwater fish. Prog Lipid Res 26, 281-347 
Hoffman LC, Prinsloo JF, Theron J, Casey NH (1995) The genotypic influence of four strains of Clarias gariepinus on the larvae body proximate total lipid fatty acid amino acid and mineral compositions. Comp Biochem Physiol B 110, 589-97

Honikel KO (1998) Reference methods for the assessment of physical characteristics of meat. Meat Sci 49, 447-57

Jobling M (2004a) »Finishing « feeds for carnivorous fish and the fatty acid dilution model. Aquacult Res 35, 706-9

Jobling M (2004b) Are modifications in tissue fatty acid profiles following a change in diet the result of dilution? Test of a simple dilution model. Aquaculture 232, 551-62

Legendre M, Kerdchuen N, Corraze G, Bergot P (1995) Larval rearing of an African catfish Heterobranchus longifilis (Teleostei Clariidae). Effect of dietary lipids on growth survival and fatty acid composition of fry. Aquat Living Res 8, 355-63

Manning BB, Li MH, Robinson EH, Peterson BC (2006) Enrichment of channel catfish (Ictalurus punctatus) fillets with conjugated linoleic acid and omega-3 fatty acids by dietary manipulation. Aquaculture $261,337-41$

Matuk K (1987) New possibilities in fish anaesthesia. Halászat 8, 11-13 [in Hungarian]

Miller MR, Nichols PD, Carter CG (2007) Replacement of dietary fish oil for Atlantic salmon parr (Salmo salar $L$ ) with a stearidonic acid containing oil has no effect on omega-3 long-chain polyunsaturated fatty acid concentrations. Comp Biochem Physiol B 146, 197-206

Regost C, Arzel J, Cardinal M, Rosenlund G, Kaushik SJ (2003) Total replacement of fish oil by soybean or linseed oil with a return to fish oil in Turbot (Psetta maxima). 2. Flesh quality properties Aquaculture 220, 737-47

Robin JH, Regost C, Arzel J, Kaushik SJ (2003) Fatty acid prifile of fish following a change in dietary fatty acid source model of fatty acid composition with a dilution hypothesis. Aquaculture 225, 283-93

Ruyter B, Rosjo C, Einen O, Thomassen MS (2000) Essential fatty acids in Atlantic salmon time course of changes in fatty acid composition of liver blood and carcass induced by a diet deficient in $n-3$ and $n-6$ fatty acids. Aquacult Nutr 6, 109-17

Ruyter B, Rosjo C, Grisdale-Helland B, Rosenlund G, Obach A, Thomassen MS (2003) Influence of temperature and high dietary linoleic acid content on esterification elongation and desaturation of PUFA in Atlantic salmon hepatocytes. Lipids 38, 833-40

SPSS 10 for Windows (1999) SPSS Inc, Chicago IL USA

Stubhaug I, Tocher DR, Bell JG, Dick JR, Torstensen BE (2005) Fatty acid metabolism in Atlantic salmon (Salmo salar $L$ ) hepatocytes and influence of dietary vegetable oil. Biochim Biophys Acta 1734, 277-88

Szabó A (2004) Effects of dietary fatty acids and physical activity on the fatty acid profile of rabbit muscles. PhD Thesis University of Kaposvár Hungary [in Hungarian]

Tocher DR, Leaver MJ, Hodgson PA (1998) Recent advances in the biochemistry and molecular biology of fatty acyl desaturases. Prog Lipid Res 37, 73-117

Torstensen BE, Frøyland L, Ørnsrud R, Lie $\varnothing$ (2004) Tailoring of a cardioprotective muscle fatty acid composition of Atlantic salmon (Salmo salar L) fed vegetable oils. Food Chem 87, 567-580

Wing-Keong N, Phaik-Kin L, Peng-Lim B (2003) Dietary lipid and palm oil source affects growth fatty acid composition and muscle a-tocopherol concentration of African catfish Clarias gariepinus. Aquaculture 215, 229-43

Werner C, Poontawee K, Mueller-Belecke A, Hoerstgen-Schwark G, Wicke M (2008) Flesh characteristics of pan-size triploid and diploid rainbow trout (Oncorhynchus mykiss) reared in a commercial fish farm. Arch Tierz 51, 71-83

Received 19 March 2008, accepted 22 February 2009.

Corresponding author:

Dr. ANDRÁS SZABÓ

email: szan1125@freemail.hu

Laboratory of Animal Product Processing, Faculty of Animal Science, University of Kaposvár, 7400

Kaposvár, Guba S. u. 40., Hungary 